\title{
ICT literacy skills proficiency and experience on the use of electronic resources amongst undergraduate students in selected Eastern Cape Universities, South Africa
}

\author{
Oluwayemi IbukunOluwa Olatoye \\ Department of Library and Information Science, University of Fort Hare, \\ Alice, South Africa \\ Fhulu Nekhwevha \\ Department of Sociology, University of Fort Hare, Alice, South Africa, and \\ Ndakasharwa Muchaonyerwa \\ Department of Library and Information Science, University of Fort Hare, \\ Alice, South Africa
}

ICT literacy skills

Received 13 August 2020 Revised 31 December 2020 Accepted 20 January 2021

\begin{abstract}
Purpose - The purpose of this paper is to investigate the levels of information and communication technology (ICT) literacy proficiency and experiences amongst Universities of Fort Hare and Rhodes undergraduate students, on the utilization of electronic resources amongst South Africa.

Design/methodology/approach - This research comprised of undergraduate students from the Universities of Fort Hare and Rhodes, who registered for a three- or four-year study. The study implemented the stratified random sampling procedure. The study's sample size was proportionally distributed amongst all the faculties common to both universities. The mixed method was applied in the study. Of the 377 administered copies of the questionnaire, 285 were returned, of which 266 were deemed useable, thereby generating a $70.6 \%$ response rate. The results were analysed using the SPSS version 26 .

Findings - Findings revealed that there is underutilization of electronic resources by the undergraduate respondents due to their low level of ICT proficiency and experience.

Originality/value - This original research article investigated the influence of ICT literacy skills proficiency and experience on the use of electronic resources amongst undergraduate students in selected Eastern Cape Universities, South Africa.
\end{abstract}

Keywords Electronic resources, e-resources, ICT literacy skills, University of Fort Hare, Rhodes University, Undergraduate students

Paper type Research paper

\section{Introduction}

Lau (2006) defined information literacy (IL) as information competencies that involve the capacity to identify when information is needed, and the skill to locate, evaluate and use information effectively. Most times, students in higher educational institutions (HEIs) often

(c) Oluwayemi IbukunOluwa Olatoye, Fhulu Nekhwevha and Ndakasharwa Muchaonyerwa. Published by Emerald Publishing Limited. This article is published under the Creative Commons Attribution (CC BY 4.0) licence. Anyone may reproduce, distribute, translate and create derivative works of this article (for both commercial and non-commercial purposes), subject to full attribution to the original publication and authors. The full terms of this licence may be seen at http://creativecommons.org/licences/by/4.0/ legalcode

Funding for this research is provided by Govan Mbeki Research and Development Centre, University of Fort Hare, Alice Campus, South Africa.

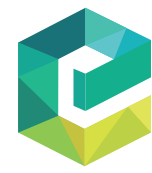

Library Management

Vol. 42 No. 6/7, 2021 pp. $471-479$

Emerald Publishing Limited 0143-5124 
LM

$42,6 / 7$

acquire their information needs through the use of electronic resources, and this depends on the level of proficiency on their skills. Skill is the ability to bring about some end result with maximum certainty and minimum outlay of time and energy. IL, which sometimes is interchangeably used by some students to mean computer literacy, only refers to the comfort level someone has with using computer programs and other applications that are associated with computers. This implies that IL is much more than computer literacy although having basic computer skill is an aspect of IL skills. Information and communication technology (ICT) literacy skills refer to effectiveness in searching for needed information. EmmanuelBaro (2009) defined ICT literacy as the capacity to solve problems of information, communication and knowledge in digital environments and indicated that ICT literacy requires both functional skills and higher-order cognitive skills. The mastery of functional skills is a prerequisite for ICT literacy since these serve as problem-solving tools in digital environments. Hence, ICT literacy is not possible without functional ICT skills. In this age of globalization, the importance of ICT to people generally and students in particular cannot be overemphasized. This is true because ICTs facilitate quick and easy access to a wide range of information/information resources worldwide. According to Emwata (2013), ICT literacy can be explained as the ability to proficiently and analytically navigate, assess and create information through the utilization of a wide range of digital technologies. Furthermore, Ukachi (2015) stated that ICT literacy necessitates the user "to recognize and use that power, to manipulate and transform electronic media, to distribute pervasively, and to easily adapt them to new forms." Academic libraries acquire and make available both printed and electronic information sources for use by the academia. To ameliorate the challenges of low ICT skills, students of HEIs should endeavour to build their ICT literacy through training and adopt ICTs to utilize current information available through electronic resources such as e-journals (Makori, 2016). Adeleke (2016) has stated that students with low levels of ICT literacy skills will underutilize electronic information resources and vice versa. The competence to retrieve and effectively utilize information is an important skill required for undergraduate academic work purposes as well as for facilitating effective use of electronic resources while in the university Emmanuel-Baro (2009).

\section{ICT literacy skills amongst undergraduate students}

Ogwu and Ogwu (2015) considered the proficiency level of ICT use amongst final year teacher trainee students at the University of Botswana and revealed that their computer proficiency was grossly inadequate. ICT literacy skills are major tools for self-actualization globally (Olatoye, 2019). As opined by Ogwu and Ogwu (2015), technological advances can harness economic prospects, increase service delivery and advance governance thereby leading to socio-economic development of the society. HEIs are incessantly updating their academic curricula to incorporate ICT literacy so as to stay abreast of fast-tracking technological advancements. According to Makori (2016), the technological advancements include the usage of classroom computers, the usage of instructive software to teach academic syllabi, library and academic materials being made available to the undergraduate via the Internet, yet, some undergraduate students in universities cannot operate a computer system without assistance even to the extent of needing help to send an e-mail.

Alemu (2015) opined that ICT literacy skills have become increasingly significant in the achievement of a degree-based education. Furthermore, they will influence students' manipulation of digital resources and the way they are utilized for learning purposes. ICT literacy skills of users relate to the users' capability of utilizing their ICT knowledge to discover, advance and represent information whether as text, number or image or an integration of these. It is suggested that in a bid to effectively utilize the developments in the ICT industry, it is germane for students to ensure the acquisition, through training in the required competencies. ICTs have greatly developed and widened the influence and 
skillfulness of their users in ways of seeking electronic information (Davies, 2011). It is on this premise that Emwanta (2013) recommended the acquisition of the optimal skills required for the maximization of ICT potentials. These skills include competence in computer procedures. Alemu (2015) disclosed that ICT skills comprise capacities such as evaluating, recognizing and efficiently utilizing given information. Hence, one should also acquire ICT literacy skills. Ukachi (2015) specified that the capability to utilize computers is not the only ICT expertise required in the exploitation of information placed on the Internet. In order to take advantage of Internet materials, one must be ICT literate. Davies (2011) affirmed that for students to be academically successful, they must obtain a number of ICT literacy skills that include understanding the use of computers in utilizing applications and generating and revising documents, spreadsheets or presentations. Some basic typing abilities are necessary as well as having the ability to identify numerous ICT technologies and their various procedures. Students must possess and practice the required skills so as to utilize the benefits of the rapidly developing array of electronic resources.

\section{Research problem}

A large body of literature (such as Momodu, 2013 and Njoroge, 2019) validates that undergraduate students underutilize electronic resources. From the foregoing, this study was prompted by the underutilization of electronic resources by undergraduates in the two selected HEIs for this study. Additionally, most universities in Africa pay huge amounts towards the establishment of ICT infrastructure, ICT literacy skills capacity building, as well as subscribing to various electronic information resources for research and learning purposes. In spite of this, e-resources utilization by students is discouraging, on account of their low levels of ICT literacy skill. As noted by Momodu (2013) and Njoroge (2019), over 50\% of sampled students were uninformed of e-information resources availability and lacked the required ICT literacy skills which negated their electronic resources usage. It is therefore on this premise that this study sought to carry out this investigation, as stated in the aim of research below.

\section{Aim of the study}

It is in the light of the above that this study sought to investigate the levels of ICT literacy proficiency and experiences amongst Universities of Fort Hare and Rhodes undergraduate students, on the utilization of electronic resources amongst South Africa.

\section{Theoretical framework}

This study applied the technology acceptance model (TAM), the theory of reasoned action (TRA) and the diffusion of information (DOI) theory as the theoretical framework underpinning the study, as they provided clearer viewpoint regarding the research direction on the underutilization of e-resources by the undergraduate students. Further, the theories enhance investigative studies on ICT literacy, thereby engendering numerous adoption standards that can be utilized when assessing the effective utilization of ICT, e-learning programmes as well as electronic resource use amongst students in HEIs. TAM and TRA play essential roles in this study regarding the motives for the belief and acceptance of technology on the use of electronic resources, thereby enhancing ICT literacy skills. Additionally, DOI underscores the need for awareness and adoption of technology on the utilization of e-information resources in conformity with ICT literacy skills of the respondents.

\section{Methodology}

The study comprised of undergraduate students from the Universities of Fort Hare and Rhodes, who registered for a three- or four-year study, leading to the award of a diploma or 
LM $42,6 / 7$

bachelor's degree. The 100 level students were exempted from the study because they were still relatively new on campus when the data were being derived. The study implemented the stratified random sampling procedure. For this study, the multifaceted sampling approach was utilized, beginning with the division of the population into sub-divisions, namely Subdivision 1: Faculty of Social Science and Humanities/Arts (SSH/Arts); Sub-division 2: Faculty of Science and Agriculture; Sub-division 3: Faculty of Law; Sub-division 4: Faculty of Education; and Sub-division 5: Faculty of Management and Commerce. The population under investigation is the undergraduates who are enrolled at the University of Fort Hare, which has undergraduate enrolment of 12,500 (UFH Institutional Planning Office) and Rhodes University which has undergraduate enrolment of 5,600 (source: www.ru.ac.za) giving a total of 18,100 undergraduate students. On account of the large study population size, systematic sample techniques will be adopted. Calculations from the Raosoft sample calculator with the level of significance at $95 \%, 5 \%$ error margin, $50 \%$ response distribution and a ballpark population size of 18,100 yielded 377 participants as this study's sample size. This was proportionally distributed amongst all the faculties common to both universities. Of the administered copies of the questionnaire, 285 were returned of which 266 were deemed useable, thereby generating a $70.6 \%$ response rate. The study used the survey design, which involved the integration of quantitative techniques in a self-administered questionnaire. In establishing the influence of ICT literacy skills (that is, experience and levels of ICT proficiency) on the undergraduates, their utilization of e-information resources regression analysis was used. The results were analysed using the SPSS version 26 and are presented below.

\section{Findings}

This section presents the research findings relating to the respondents' experience and their proficiency in using ICT facilities, followed by results on regression analyses and means of acquisition of ICT skills. Results in Table 1 depict that $40(15 \%)$ respondents (out of a total number $N=266$ ) possess experience of more than nine years on the use of desktop or laptop computers; $46(17.3 \%)$ respondents had more than nine-year experience in the use of the web (WWW), and an equal number (46) had experience in the use of search engines. Furthermore, respondents who had four to six years of experience in the use of digital electronic media were $53(19.9 \%)$, while $76(28.6 \%)$ respondents had less than a year of experience in using digital repositories. It can also be observed that $62(23.3 \%)$ respondents had one to three years of experience in the use of electronic library resources. Table 1 depicts the years of experience and proficiency of undergraduate students in using ICT facilities.

Table 1.

Years of experience and proficiency in using ICT

facilities $(N=266)$

\begin{tabular}{|c|c|c|c|c|c|c|}
\hline & ICT facilities & $\begin{array}{l}\text { Less than } 1 \\
\text { year }\end{array}$ & $1-3$ years & 4-6 years & 7-9 years & $\begin{array}{c}\text { Above } 9 \\
\text { years }\end{array}$ \\
\hline & Electronic mail (e-mail) & $42(15.8 \%$ & $71(26.7 \%)$ & $41(15.4 \%)$ & $30(11.3 \%)$ & $37(13.9 \%)$ \\
\hline b & Deskto & $41(15$. & $3(2$ & $44(16.5 \%)$ & $35(13$ & $40(15 \%)$ \\
\hline c. & World Wide Web document & $41(15.4 \%)$ & $57(21.4 \%)$ & $32(12 \%)$ & $28(10.5 \%)$ & $46(17.3 \%)$ \\
\hline 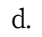 & Search & 51 (19 & $\%)$ & $34(12.8 \%)$ & $30(11.3 \%)$ & $46(17.3 \%)$ \\
\hline c. & Electronic library resources & $60(2$ & 62( & $47(1$ & $21(7.9 \%)$ & $19(7.1 \%)$ \\
\hline$f$ & $\begin{array}{l}\text { Audio and video } \\
\text { communication }\end{array}$ & $52(19.5 \%)$ & $62(23.3 \%)$ & $46(17.3 \%)$ & $21(7.9 \%)$ & $25(9.4 \%)$ \\
\hline g. & Online repositories & $76(28.6 \%)$ & $56(21.1 \%)$ & $32\left(12^{\circ}\right.$ & $17(6.4 \%)$ & $19(7.1 \%)$ \\
\hline . & Digital electronic media & $52(19.5 \%)$ & $52(19.5 \%)$ & $53(19.9 \%)$ & $20(7.5 \%)$ & $29(10.9 \%)$ \\
\hline
\end{tabular}


In Table 1, most undergraduate students, i.e. 76 (28.6\%) make use of online repositories, while $60(22.6 \%)$ make use of electronic library resources, with less than one year of experience and proficiency. Also, about $41(15.4 \%)$ make use of desktop/laptop computers. In addition, digital electronic media has been used by $52(19.5 \%)$ of the surveyed students for a period of less than a year. From the research findings, it was observed that many respondents still had less than a year of experience in their use of the ICT facilities and electronic resources. Hence, the result indicates that there is still underutilization of the ICT facilities by the respondents. Table 2 shows the level of proficiency in ICT skills.

In Table 2, the highest number of respondents, i.e. $68(25.6 \%)$ had fair assessment on their use of search strategies, and $71(26.7 \%)$ respondents had fair knowledge on the performance of data analysis. Further, $67(25.2 \%)$ respondents can fairly use an e-learning platform, while $57(21.4 \%)$ respondents were very poor at utilizing search strategies. The findings show that a significant number of respondents still had poor or fair skills in the utilization of electronic resources. Table 3 presents analysis on research hypothesis for the study.

\section{Regression analysis test for hypothesis}

Table 3 proposed a hypothesis showing relationship between ICT experience and levels of ICT proficiency of undergraduate students towards the use of electronic resources that was tested in the research in a bid to understand the relationship between the variables. The following hypothesis was subjected to test at 0.05 level of significance:

H01. There is no significant relationship between ICT experience and levels of ICT proficiency of undergraduate students towards their utilization of e-information resources. The regression analysis test of the hypothesis is given in Table 3.

The result in Table 3 shows that there is significant relationship between ICT experience and levels of ICT proficiency of undergraduate students regarding their utilization of electronic resources $(\phi \leq 0.05)$. This implies that ICT experience of the undergraduate students affect

\begin{tabular}{|c|c|c|c|c|c|c|c|}
\hline $\begin{array}{l}\mathrm{S} / \\
\mathrm{N}\end{array}$ & ICT skills & Poor & Fair & Good & Very good & Excellent & \\
\hline a. & $\begin{array}{l}\text { I can independently operate } \\
\text { personal computer systems }\end{array}$ & $9(3.4 \%)$ & $37(13.9 \%)$ & $70(26.3 \%)$ & $49(18.4 \%)$ & $65(24.4 \%)$ & \\
\hline b. & Use software for preparing work & $16(6 \%)$ & $34(12.8 \%)$ & $54(20.3 \%)$ & $50(18.8 \%)$ & $70(26.3 \%)$ & \\
\hline c. & Use software for presenting work & $16(6 \%)$ & $34(12.8 \%)$ & $62(23.3 \%)$ & $45(16.9 \%)$ & $68(25.6 \%)$ & \\
\hline d. & $\begin{array}{l}\text { Use Internet and its various } \\
\text { features }\end{array}$ & $4(1.5 \%)$ & $13(4.9 \%)$ & $55(20.7 \%)$ & $60(25.6 \%)$ & $91(34.2 \%)$ & \\
\hline e. & $\begin{array}{l}\text { Access information from the } \\
\text { WWW }\end{array}$ & $2(0.8 \%)$ & $24(9 \%)$ & $50(18.8 \%)$ & $58(21.8 \%)$ & $91(34.2 \%)$ & \\
\hline f. & Use an e-learning platform & $23(8.6 \%)$ & $67(25.2 \%)$ & $51(19.2 \%)$ & $33(12.4 \%)$ & $45(16.9 \%)$ & \\
\hline g. & $\begin{array}{l}\text { Perform data analysis with a } \\
\text { computer package }\end{array}$ & $40(15 \%)$ & $71(26.7 \%)$ & $48(18 \%)$ & $24(9 \%)$ & $37(13.9 \%)$ & \\
\hline h. & $\begin{array}{l}\text { Can use electronic information } \\
\text { sources }\end{array}$ & $14(5.3 \%)$ & $52(19.5 \%)$ & $69(25.9 \%)$ & $44(16.5 \%)$ & $44(16.5 \%)$ & \\
\hline i. & $\begin{array}{l}\text { Ability to utilize e-information } \\
\text { resources }\end{array}$ & $19(7.1 \%)$ & $43(16.2 \%)$ & $55(20.7 \%)$ & $51(19.2 \%)$ & $56(21.1 \%)$ & \\
\hline j. & $\begin{array}{l}\text { I can easily initiate search } \\
\text { strategies }\end{array}$ & $57(21.4 \%)$ & $68(25.6 \%)$ & $45(16.9 \%)$ & $27(10.2 \%)$ & $27(10.2 \%)$ & \\
\hline $\mathrm{k}$. & $\begin{array}{l}\text { Searching indexes and electronic } \\
\text { databases }\end{array}$ & $34(12.8 \%)$ & $60(22.6 \%)$ & $53(19.9 \%)$ & $42(15.8 \%)$ & $35(13.2 \%)$ & $\begin{array}{l}\text { Level of proficiency in } \\
\text { ICT skills on electronic }\end{array}$ \\
\hline 1. & Evaluate WWW sources & $27(10.2 \%)$ & $57(21.4 \%)$ & $60(22.6 \%)$ & $44(16.5 \%)$ & $30(11.3 \%)$ & resource use $(N=266)$ \\
\hline
\end{tabular}

ICT literacy skills $\longrightarrow$ 
LM $42,6 / 7$

Table 3.

Regression analysis showing relationship between ICT experience and levels of ICT proficiency of undergraduate students towards the use of electronic resources their proficiency levels. Table 4 presents the means of acquisition of ICT skills by the respondents. Results from the means of ICT acquisition of respondents are depicted below.

Table 4 indicates that most respondents, i.e. 121 (45.5\%) personally developed themselves with the e-mail, while $71(26.7 \%)$ developed their file transfer skills through formal teaching. Also, $72(27.1 \%)$ of respondents learnt audio and video communication through friends, while $35(13.2 \%)$ of the surveyed students learnt online database management through colleagues. From the findings, it is revealed that most of the undergraduate students learnt the use of e-mail on their own. This could be due to the fact that their academic handouts and communication from their lecturers and other academic information were usually sourced from their personal school mails. Hence, most of the respondents had to develop their skills in this area so as to retrieve school-related information from their personal mails. Table 5 analyses the ICT literacy skills of respondents and their utilization of e-information resources.

Table 5 reveals that $79(29.7 \%)$ respondents agree with the notion that inadequate knowledge of ICT skills can limit productive use of e-resources. Also, $98(36.8 \%)$ respondents agree that poor level of ICT literacy skills can hinder the use of electronic information resources; $93(34.9 \%)$ of the surveyed students agree that possession of IL skills will enhance the utilization of electronic resources, but on the contrary, $4(1.5 \%)$ strongly disagree with the notion. Also, $75(34.9 \%)$ respondents agreed that ability to independently operate a computer makes it possible for one to access e-resources. Furthermore, $90(33.4 \%)$ respondents agree that lack of computer skills can negatively affect the ability to access electronic resources.

\section{Conclusion}

This paper addressed the ICT Literacy skills proficiency and experience on the use of electronic resources amongst undergraduate students in selected Eastern Cape universities, South Africa. The general findings reveal that ICT proficiency and experience of the undergraduate respondents on their use of electronic resources is generally low, and this can limit their productive use of e-resources, thereby supporting the notion that proficiency in

\begin{tabular}{lcccc}
\hline Model & Unstandardized coefficients & Standard coefficients & & \\
& $B /$ Std. error & Beta & $T$ & Sig. \\
\hline (Constant) & $2.338 / 0.133$ & 0.495 & 17.610 & 0.000 \\
Period of ICT experience & $0.399 / 0.049$ & & 8.217 & 0.000 \\
Dependent variable: ICT proficiency & & & & \\
\hline
\end{tabular}

Table 4.

Means of acquisition of ICT skills $(N=266)$

\begin{tabular}{|c|c|c|c|c|c|}
\hline & Internet facilities & Personal development & Formal & Friends & Colleagues \\
\hline 1. & Electronic mail & $121(45.5 \%)$ & $50(18.8 \%)$ & $38(14.3 \%)$ & $19(7.1 \%)$ \\
\hline 2. & File transfer & $68(25.6 \%)$ & $71(26.7 \%)$ & $55(20.7 \%)$ & $19(7.1 \%)$ \\
\hline 3. & World Wide Web document & $80(30.1 \%)$ & $80(30.1 \%)$ & $41(15.4 \%)$ & $23(8.6 \%)$ \\
\hline 4. & Search engines & $84(31.6 \%)$ & $59(22.2 \%)$ & $43(60.2 \%)$ & $21(7.9 \%)$ \\
\hline 5. & Global digital library & $62(23.3 \%)$ & $81(30.5 \%)$ & $35(13.2 \%)$ & $19(7.1 \%)$ \\
\hline 6. & Audio and video communication & $85(32 \%)$ & $32(12 \%)$ & $72(27.1 \%)$ & $13(4.9 \%)$ \\
\hline 7. & Online repositories & $69(25.9 \%)$ & $66(24.8 \%)$ & $49(18.4 \%)$ & $13(4.9 \%)$ \\
\hline 8. & Digital electronic media & $76(28.6 \%)$ & $64(24.1 \%)$ & $44(16.5 \%)$ & $17(6.4 \%)$ \\
\hline 9. & Online database & $78(29.3 \%)$ & $65(24.4 \%)$ & $29(10.9 \%)$ & $35(13.2 \%)$ \\
\hline
\end{tabular}




\begin{tabular}{|c|c|c|c|c|c|c|}
\hline ICT literacy skills/e-resources use & $\begin{array}{l}\text { Strongly } \\
\text { disagree }\end{array}$ & Disagree & Neutral & Agree & $\begin{array}{l}\text { Strongly } \\
\text { agree }\end{array}$ & $\begin{array}{r}\text { IC1 literacy } \\
\text { skills }\end{array}$ \\
\hline $\begin{array}{l}\text { 1. Inadequate knowledge of ICT } \\
\text { skills can limit productive use of } \\
\text { e-resources }\end{array}$ & $17(6.4 \%)$ & $21(7.9 \%)$ & $40(15 \%)$ & $79(29.7 \%)$ & $58(21.8 \%)$ & \\
\hline $\begin{array}{l}\text { 2. Poor level of ICT literacy skills can } \\
\text { hinder the use of electronic } \\
\text { information resources }\end{array}$ & $9(3.4 \%)$ & $14(5.3 \%)$ & $34(12.8 \%)$ & $98(36.8 \%)$ & $59(22.2 \%)$ & 477 \\
\hline $\begin{array}{l}\text { 3. Lack of ICT competency leads to } \\
\text { ineffective use of electronic } \\
\text { information resources }\end{array}$ & $9(3.4 \%)$ & $12(4.5 \%)$ & $32(12 \%)$ & $94(35.3 \%)$ & $66(24.8 \%)$ & \\
\hline $\begin{array}{l}\text { 4. ICT literacy is important in the use } \\
\text { of electronic resources }\end{array}$ & $6(2.3 \%)$ & $7(5.6 \%)$ & $24(9 \%)$ & $90(33.4 \%)$ & $87(32.7 \%)$ & \\
\hline $\begin{array}{l}\text { 5. Possession of information literacy } \\
\text { skills will enhance the use of } \\
\text { electronic resources }\end{array}$ & $4(1.5 \%)$ & $17(6.4 \%)$ & $33(12.4 \%)$ & $93(34.9 \%)$ & $67(25.2 \%)$ & \\
\hline $\begin{array}{l}\text { 6. Ability to independently operate a } \\
\text { computer makes it possible for one to } \\
\text { access electronic resources }\end{array}$ & $9(3.4 \%)$ & $20(7.5 \%)$ & $37(13.9 \%)$ & $75(28.2 \%)$ & $74(27.8 \%)$ & \\
\hline $\begin{array}{l}\text { 7. Possession of ICT skills is a key } \\
\text { ingredient of the ability to use }\end{array}$ & $2(0.7 \%)$ & $16(6 \%)$ & $44(16.5 \%)$ & $88(33.1 \%)$ & $62(33.3 \%)$ & \\
\hline $\begin{array}{l}\text { 8. Lack of ability to operate a } \\
\text { computer is a deterrent to the } \\
\text { utilization of e-information resources }\end{array}$ & $5(1.9 \%)$ & $13(4.9 \%)$ & $49(18.4 \%)$ & $86(32.3 \%)$ & $60(22.6 \%)$ & \\
\hline $\begin{array}{l}\text { 9. Competencies to use a computer } \\
\text { make it possible for you to access } \\
\text { electronic resources }\end{array}$ & $6(2.3 \%)$ & $19(7.1 \%)$ & $44(16.5 \%)$ & $89(33.5 \%)$ & $56(261.1 \%)$ & \\
\hline $\begin{array}{l}\text { 10. Lack of computer skills can } \\
\text { negatively affect the ability to access } \\
\text { electronic resources }\end{array}$ & $5(1.9 \%)$ & $13(4.9 \%)$ & $35(13.2 \%)$ & $90(33.8 \%)$ & $73(27.4 \%)$ & \\
\hline $\begin{array}{l}\text { 11. Familiarity with ICT literacy } \\
\text { skills has a major influence on } \\
\text { effective utilization of electronic } \\
\text { resources }\end{array}$ & $8(3 \%)$ & $12(4.5 \%)$ & $40(15 \%)$ & $87(32.7 \%)$ & $67(25.2 \%)$ & \\
\hline $\begin{array}{l}\text { 12. Capacity building workshops on } \\
\text { ICT literacy skills has an effect on the } \\
\text { frequency and quality of electronic } \\
\text { resources use }\end{array}$ & $8(3 \%)$ & $12(4.5 \%)$ & $54(20.3 \%)$ & $95(35.7 \%)$ & $47(17.7 \%)$ & \\
\hline $\begin{array}{l}\text { 13. There exists a relationship } \\
\text { between ICT literacy skills and the } \\
\text { utilization of e-information resources }\end{array}$ & $8(3 \%)$ & $12(4.5 \%)$ & $54(20.3 \%)$ & $95(35.7 \%)$ & $47(17.7 \%)$ & \\
\hline 14. There is a positive correlation & $8(3 \%)$ & $11(4.1 \%)$ & $49(18.4 \%)$ & $93(34.9 \%)$ & $50(18.8 \%)$ & \\
\hline $\begin{array}{l}\text { existing between the ICT literacy } \\
\text { skills and quality electronic } \\
\text { resources use } \\
15 \text {. There is no correlation between } \\
\text { the ICT literacy skills and effective } \\
\text { utilization of e-information resources }\end{array}$ & $33(12.4 \%)$ & $65(24.4 \%)$ & $50(18.8 \%)$ & $41(15.4 \%)$ & $21(7.9 \%)$ & $\begin{array}{r}\text { Table 5. } \\
\text { ICT literacy skills of } \\
\text { respondents and their } \\
\text { utilization of } \\
\text { e-information } \\
\text { resources }(N=266)\end{array}$ \\
\hline
\end{tabular}

ICT literacy skills has a major influence on effective utilization of e-resources amongst the respondents.

\section{Recommendation}

As regards the ICT literacy skills proficiency and experience on the use of electronic resources amongst undergraduate students, the following recommendations are made 
LM

$42,6 / 7$
(1) Building of capacity of the undergraduate students in the use of electronic resources through ICT literacy skill development programmes, which should be incorporated in the curriculum of the undergraduate students.

(2) There is need for intervention focussing on the application of some e-resources and software where the students are ranked low.

(3) Provision and empowering of Wi-Fi services in the lecture rooms, student libraries as well as the official residences of the undergraduate students.

(4) Provision of electronic databases, which will help to address the difficulties encountered in online Internet environments.

\section{References}

Adeleke, D.S. and Emeahara, E.N. (2016), "Relationship between information literacy and use of electronic information resources by postgraduate students of the University of Ibadan", Library Philosophy and Practice (e-journal), 17 p. 1381, ISSN: 1522-0222.

Alemu, B.M. (2015), "Integrating ICT into teaching-learning practices: promise, challenges and future directions of higher educational institutes", Universal Journal of Educational Research, Vol. 3 No. 3, pp. 170-189.

Davies, R.S. (2011), "Understanding technology literacy: a framework for evaluating educational technology integration", TechTrends, Vol. 55 No. 5, p. 45.

Emmanuel-Baro, E. and Fyneman, B. (2009), "Information literacy among undergraduate students in Niger Delta University", The Electronic Library, Vol. 27 No. 4, pp. 659-675.

Emwanta, M.G. and Nwalo, K.I.N. (2013), "Influence of computer literacy and subject background on use of electronic resources by undergraduate students in universities in South-western Nigeria", International Journal of Library and Information Science, Vol. 5 No. 2, pp. 29-42.

Lau, J. (2006), Guidelines on Information Literacy for Lifelong Learning, IFLA, Veracruz.

Makori, E.O. and Mauti, N.O. (2016), "Digital technology acceptance in transformation of university libraries and higher education institutions in Kenya", Library Philosophy and Practice (e-journal) 20 p. 1379, ISSN: 1522- 0222.

Momodu, O.M. (2013), "Library utilization among college of medicine research year undergraduates: case study of Ambrose Alli university, Ekpomanigeria”, International Journal of Basic, Applied and Innovative Research, Vol. 2 No. 4, pp. 106-111.

Njoroge, K. (2019), "Influence of information literacy on utilization of electronic resources by bachelor of education teacher trainees", Doctoral dissertation, UoN, University of Nairobi, Kenya.

Ogwu, E.N. and Ogwu, F.C. (2015), "Comparative analysis of microsoft package (MSP) competence among teacher trainee students in Botswana and Nigeria: implications for curriculum practices", Journal of Education and Practice, Vol. 7 No. 27, pp. 157-164.

Olatoye, O.I. (2019), "ICT literacy skills and demographic factors as determinants of electronic resources use among undergraduate students in the University of Fort Hare and Rhodes University, Eastern Cape, South Africa”, Doctor of Philosophy (PhD) Research theses, Department of Library and Information Science, Faculty of Social Science and Humanities, University of Fort Hare, Eastern Cape.

Ukachi, N.B. (2015), "Information literacy of students as a correlate of their use of electronic resources in university libraries in Nigeria”, The Electronic Library, Vol. 33 No. 3, pp. 486-501, doi: 10. 1108/EL-05-2013-0085.

\section{Further reading}

Bartels, K.P. (2015), Communicative Capacity: Public Encounters in Participatory Theory and Practice, Policy Press, Bristol. 
JinGubbiMarusic, J.J.S. and Palaniswami, M. (2014), "An information framework for creating a smart city through internet of things", IEEE Internet of Things Journal, Vol. 1 No. 2, pp. 112-121.

Lundblad, J.P. (2003), "A review and critique of Rogers' diffusion of innovation theory as it applies to organizations", Organization Development Journal, Vol. 21 No. 4, p. 50.

Malhotra, Y. and Galletta, D.F. (1999), "Extending the technology acceptance model to account for social influence: theoretical bases and empirical validation", Proceedings of the 32nd Annual Hawaii International Conference on Systems Sciences. 1999. HICSS-32. Abstracts and CD-ROM of Full Papers, IEEE, p. 14.

\section{About the authors}

Dr. Oluwayemi IbukunOluwa Olatoye was appointed Post-Doctoral Fellow in the Department of Library and Information Science, University of Fort Hare, South Africa in August, 2019. Dr. Olatoye completed her Masters and doctoral degrees at the Universities of Ibadan, Nigeria, and Fort Hare respectively. Her research interests include ICT literacy, electronic resources utilization, and knowledge management. She has published widely in these fields. Oluwayemi IbukunOluwa Olatoye is the corresponding author and can be contacted at: yolatoye19@gmail.com

Prof. Fhulu Nekhwevha is a professor in the Department of Sociology and the Acting Executive Dean (Teaching and Learning) in the Faculty of Social Sciences and Humanities at the University of Fort Hare. He was formally the Vice president of the South African Sociological Association. He has particular research interests in the sociology of education and sustainable development, and he is actively involved in community engagement. His published research articles have engaged in series of societal issues such as education transformation and the African Renaissance in a globalizing world, utilization of library information resources, the integrated development plan and women empowerment, poverty attribution, livelihood chances of rural older adults and marginalised indigenous knowledge in food production processes.

Dr. Ndakasharwa Muchaonyerwa is a Senior Lecturer and Head of Department in the Department of Library and Information Science at University of Fort Hare, Alice, South Africa. Her teaching and research areas include Knowledge Management, Information Retrieval, Research Methods, Library Information Science Education and Training, Information and Communication Technologies (ICTs). The research modules she teaches at UFH include Information Retrieval, Management Studies and User Studies. She serves as a Board member of the Library Association of South Africa (LIASA).
ICT literacy skills

For instructions on how to order reprints of this article, please visit our website:

www.emeraldgrouppublishing.com/licensing/reprints.htm

Or contact us for further details: permissions@emeraldinsight.com 